\title{
Partisipasi Teritorial Masyarakat Lingkar Tambang Morosi Kabupaten Konawe
}

\author{
Alamsyah ${ }^{1}$, Agustang ${ }^{2}$, Arlin Adam ${ }^{3}$, Andi Alim ${ }^{4}$ \\ Universitas Negeri Makassar ${ }^{1,2}$ \\ Universitas Pejuang Republik Indonesia ${ }^{3,4}$ \\ Email: alsdandy1005@gmail.com
}

\begin{abstract}
Abstrak. Masa setelah kemerdekaan, konsep pertahanan semesta yang bersifat kerakyatan mengalami degradasi, yang ditandai berkurangnya partisipasi masyarakat dalam sistim pertahanan teritori di beberapa wilayah. Tumpuan utama pertahanan negara diletakkan secara penuh pada militer, padahal potensi ancaman terhadap keutuhan dan kedaulatan negara RI tetapada, khususnya pada wilayah lingkar tambang dengan tenaga kerjaasingnya. Penelitian ini bertujuan mengungkap secara mendalam fenomena rendahnya partisipasi masyarakat dalam sistim pertahanan teritori menurut sudut pandang sosiologi militer. Metode penelitian kualitatif dengan pendekatan fenomenologi berupaya mengungkap makna-makna sentral yang dipahami masyarakat sebagai dasar bertindak secara sosial. Informan dipilih melalui teknik purposive sampling sebanyak 18 orang terdiri dari kalangan militer aktif dan masyarakat sekitar lokasi tambang. Analisa dan penyajian data secara deskriptif dengan menampil kan kutipan-kutipan pernyataan informan. Hasil penelitian menemukan transformasi jenis pekerjaan, pengetahuan, persepsi, dan pola relasi sosial Badan Pembina Desa (Babinsa) mendeterminasi rendahnya partisipasi masyarakat dalam pembinaan teritorial (Binter) di lingkar tambang. Model pembinaan teritorial membutuhkan adaptasi yang menyesuaikan struktur dasar masyarakat industri.
\end{abstract}

Kata Kunci: Partisipasi, Teritorial, Militer, Industri

\section{PENDAHULUAN}

Awal perang kemerdekaan Indonesia (agresibelanda I tahun 1947), tentara teritorial dengan rakyat mempunyai tugasmempertahankan wilayah. Agar tentara teritorial dapat menjalankan tugasnya, dibutuhkan perlindungan dari tentara mobil terhadap serangan besar-besaran pihak musuh. Selain itu, membutuhkan bantuan dari rakyat berupa harta benda maupun tenaganya. Rakyat bertugas memproduksi bahan perbekalan (makanan) sebanyak-banyaknya dan membantu pemerintahan dalam segala bidang.

Pada masa pasca kemerdekaan, Komando Teritorial (Koter) beserta pembinaan teritorialnya tetap digunakan dengan alasan masih terdapat ancaman terhadap negara, khususnya ancaman terhadap ideologi Pancasila dan UndangUndang Dasar 1945. Berawal konsep "Jalan Tengah" dan doktrin "Tri UbayaCakti" 
yang melegitimasi Dwifungsi $A B R I$ bahwasanya militer memiliki tiga tugas utama yaitu pertahanan darat nasional, doktrin kekaryaan dan doktrin pembinaan.

Seiring dengan perubahan politik negara, konsepsi ancaman, reorganisasi di tubuh TNI dan dinamika sosial yang terjadi, konsep Komando Teritorial tetapdi teruskan. Melalui pembinaan teritorial (Binter) diharapkantercapaipenggunaan kemampuan TNI AD dalam membantu pemerintah mensejahterakan masyarakat, tereliminirnya konflik komunal dan radikalisme, termasuk terbangun dan terpeliharanya wawasan kebangsaan, kesadaran bela negara masyarakat lokal.

Pembinaan teritorial menuntut adanya hubungan yang erat dan saling menguntungkan antara TNI dan rakyat atau lebih populer denganis tilah Kemanunggalan TNI - Rakyat yang menjadi sumber kekuatan Pertahanan Semesta. Pelibatan masyarakat bersama TNI menyiapkan wilayah pertahanan serta perlawanan rakyat guna menjamin terselenggaranya Sistem Pertahanan Semesta yang memiliki kemampuan menghadapi situasi kritis dan meniadakan ancaman dari dalam serta menangkal ancaman dari luar (Departemen Pertahanan Indonesia., 2008).

Program pembinaan teritorial tidakakan berjalan tanpa adanya partisipasi masyarakat. Banyak ahli memberikan pengertian mengenai konsep partisipasi. Slamet (1994) mengatakan bahwa partisipasi berarti peran serta seseorang atau kelompok masyarakat secara aktif dari proses perumusan kebutuhan, perencanaan, sampai pada tahap pelaksanaan kegiatan baik melalui pikiran atau langsung dalam bentuk fisik.

Sebagaimana beberapa wilayah lainnya di Indonesia, di Kec. Morosi Kab. Konawe juga merupakan daerah pengembangan pabrik vero nikel terbesar di Sulawesi Tenggara. Di dalam kawasan industri ini, terdap atribuan tenaga kerja asing (China) maupun tenaga kerja yang berasal dari berbagai daerah nusantara serta tenaga kerja lokal. Mereka yang terdiri dari bebagai etnik dan suku berbaur dengan masyarakat setempat, melakukan aktivitas ekonomi dan sosial. Di daerah inilah dengan berbagai variannya, menarik bagi penulis untuk meneliti tentang partisipasi teritorial masyarakat.

\section{METODOLOGI}

Jenis penelitian ialah kualitatif, yaitu suatu penelitian ilmiah yang bertujuan untuk memahami suatu fenomen adalam konteks sosial secara alamiah dengan mengedepankan proses interaksi komunikasi yang mendalam antara peneliti dengan fenomena yang diteliti (Andi Agustang, 2015). Sedangkan metode yang digunakan fenomenologi, yaitu penelitian yang menggambarkan pemaknaan beberapa individu mengenai pengalaman hidupnya, terhadap konsep atau fenomena tertentu. Adapun paradigma penelitian ialah konstruktivisme, dimana kebenaran suatu realitas sosial dilihat sebagai hasil konstruksisosial dan kebenaran suaturea litassosial bersifat relatif (Agustang, 2021). 
Penelitian dilaksanakan di wilayah lingkar tambang Morosi Kabupaten Konawe Sulawesi Tenggara. Informan dipilih dengan cara purposive sampling yaitu teknik pengambilan sumber data dengan pertimbangan tertentu. Sumber data dianggap paling tahu tentang apa yang diharapkan (Agustang, 2011). Selain itu, dilakukan dengan cara mengambil subjek berdasarkan atas tujuanter tentu. Informan terdiri Danramil dan Babinsa 3 orang, dari tokoh masyarakat 3 orang, camat/kepaladesa 2 orang serta warga dengan berbagai profesi 10 orang.

Dalam penelitian ini, pengumpulan data hanya dilakukan melalui wawancara dengan proses tanya jawab lisan yang berlangsung satu arah, artinya pertanyaan berasal dari pihak yang mewawancarai dan jawaban diberikan oleh yang diwawancarai. Proses wawancara dilakukan langsung dan terbuka agar data yang diperoleh lebih banyak dari subjek yang diteliti dan tentunya dengan cara deskripsi dalam bentuk kata-kata dan Bahasa, pada suatu konteks khusus yang alamiah dan dengan memanfaatkan berbagai metode ilmiah (Moleong, 2007).

\section{HASIL DAN PEMBAHASAN}

Kecamatan Morosi merupakan bagian dari Kabupaten Konawe Propinsi Sulawesi Tenggara, dengan luas $76.49 \mathrm{Km}^{2}$. Jumlah penduduk 10.645 jiwa mendiami sepuluh desanya itu desa Mendikonu, Wonua Morini, Besu, Paku, Puuruy, Morosi, Tanggoba, Paku Jaya, Tondowatu dan Desa Porara. Penduduknya terdiri dari suku Tolaki, Bugis, Makassar, Buton, Muna, Jawa dan lainnya, dengan mayoritas beragama Islam. (Kecamatan Morosidalam Angka 2019). Namun, fakta di lapangan menunjukkan bahwa jumlah penduduk khususnya di desa Morosi sangat besar oleh adanya warga pendatang yang tinggal di Kos-kosan yang sulit didata secara resmi oleh pemerintah daerah maupun instansi terkait. Sebagian besar dari mereka bermatapencaharian sebagai pekerja di pabri knikel, petani, petambak dan pengolahan pasir.

Pada tahun 2014 di desa Morosi dan desa Porara mulai di bangun pabrik veronikel Perusahaan Modal Asing (PMA) PT Virtue Dragon Nickel Industry (VDNI) yang merupakan anak usaha De Long Nickel Co Ltd yang berasal dari Jiangsu China. VDNI merupakan salah satu pemegang izinu saha pertambangan khusus. Perusahaan ini berinvestasi 1,4 miliar dollar AS atau sekitar Rp 19,6 triliun. Kemudian tahun 2018 didirikan PT Obsidian Stainless Steel (OSS).

Seiring dengan dibangunnya industrinikel tersebut, tenaga kerja China mulai berdatangan di daerah Morosi. Sesuai data dari Disnaskertrans Sulawesi Tenggara per tanggal 18 Februari 2019 jumlah tenaga kerja asing khusus untuk yang bekerja di PT. VDNI berjumlah sebanyak 1452 pekerja. Tenaga kerja China secara tidak langsung berinteraksi dan berbaur dengan 11 ribu lebih tenaga kerja lokal yang bekerja pada perusahaan VDNI dan OSS serta masyarakat yang berada di sekitar kawasan industri tersebut (Rahadi, 2020). 
Sebelum berdirinya kawasan industri, kehidupan masyarakat Morosi sangat terbatas dalam aspek waktu maupun mata pencaharian. Saat ini, setiap hari aktivitas masyarakat dan pekerja di kawasan industri tersebut, berlangsung selama 24 jam. Orang-orang keluar masuk hanya untuk kerja. Lalu lintas kendaraan (sepeda motor dan mobil) cukup padat melintasi ruas jalan di kawasan industri dan sekitarnya. Disamping banyak tenaga kerja yang terserap, juga berkembang kecenderungan masyarakat mencari rejeki dengan mendirikan rumah kos, membuka toko sandang pangan maupun barang elektronik, warung makan dan minum, jasa ojek dan kegiatan pelayanan jasa lainnya. Interaksi ekonomi yang tinggi dikalangan masyarakat dan adanya investasi sub-kontraktor perusahaan VDNI telah meningkatkan penghasilan masyarakat Morosi.

Semenjak pemerintah pusat menetapkan Kabupaten Konawe, Sulawesi Tenggara sebagai Kawasan Ekonomi Khusus (KEK), daerah lingkar tambang Morosi selalu menjadi sorotan berbagai kalangan. Bermacam konfliktelah terjadi, mulai dari proses pembangunan smelter hingga saat ini, ketika pabrik sudah memproduk siveronikel. Perkelahian diantara pekerja lokal, pekerja lokal dengan pekerja China, masyarakat dengan pekerja China, konflik antara pekerja lokal dan masyarakat dengan pihak perusahaan. Intensitas dan motifnya pun beragam, mulai dari persoalan pribadi, sampai pada ketersinggungan rasial, dengan konflik disertait indakan destruktif dan kerusuhan yang mengancam stabilitas daerah.

Dalam Doktrin Induk Teritorial TNI AD (2018), dijelaskan bahwa penggunaan Binter pada tugas Operasi Militer Selain Perang (OMSP) yang bersifatnon tempur, antara lain memberdayakan wilayah pertahanan dan kekuatan pendukungnya secara dinisesuai dengan Sistem Pertahanan Semesta (Sishanta). Membantu tugas pemerintahan di daerah dalam rangka mengatasi kesulitan rakyat, kelancaran tatanan pemerintahan di daerah rawan; dan membantu mengatasi akibat bencana alam dan dampak ikutannya, merehabilitasi infrastruktur, mengatasi masalah akibat pemogokan, konflik komunal. Selain itu, membantu Kepolisian Negara Republik Indonesia berkaitan tugas keamanan ketertiban masyarakat yang diatur dalam undang-undang.

Pembinaan teritorial menggunakan 3 (tiga) metoda. MetodaPembinaan Komunikasi Sosial dilaksanakan untuk memelihara serta meningkatkan keeratan hubungan dengan segenap komponen bangsa guna terwujudnya saling pengertian dan kebersamaan yang memungkinkan timbulnya keinginan dan peran sertamasyarakat dalam berpartisipasi bagikepentingan bidang pertahanan negara. Metoda Bakti TNI dilaksanakan dalam rangka membantu pemerintah meningkatkan kesejah teraan masyarakat dan memantapkan kemanunggalan TNI-Rakyat dalam rangka menyiapkan ruang, alat dan kondisi Juang yang tangguh untuk kepen tingan pertahanan negara. Kegiatan Bakti TNI tersebut dilaksanakan melalui kegiatan TNI 
Manunggal Membangun Desa (TMMD), KaryaBakti (Karbak), Bakti Sosial (Baksos), dan Penanggulangan Bencana (Gulben).

Sedangkan metoda Pembinaan Ketahanan Wilayah dilaksanakan dengan kegiatan pembinaan rencana tata ruang wilayah (RT/RW) pertahanan darat, pembinaan Pramuka, pembinaan toleransi antar umat beragama, budaya, adatistiadat dan seni budaya. Selain itu, pembinaan kegiatan antisipasi bahaya laten komunis dan deradikalisasi, penataran kader bela negara, peningkatan pendidikan masyarakat miskin, masyarakat di wilayah terpencil, pedalaman, wilayah perbatasan, pulauter depan, dan terluar serta pengentasan buta aksara, serta kegiatan pelatihan keterampilan masyarakat sesuai profesi untuk diberdayakan guna meningkatkan taraf hidup dan kesejahteraan.

Pada tataran operasional, penggunaan metode Binter di wilayah Morosi disesuaikan dengan kondisi wilayah dan dinamika kehidupan yang terjadi. Pelibatan secara maksimal aparat teritorial diprioritaskan terhadap wilayah dan masyarakat yang menghadapi berbagai bentuk permasalahan krusial dan kritis, seperti berkembangnya wabah penyakit, kemiskinan, ancaman keamanan dan konflik serta bencana alam.

Dengan masuknya ratusan tenaga kerja asing (China) dan berinteraksi dengan masyarakat (pekerjalokal), maka sedikit banyaknya akan mempengaruhi carapan dang masyarakat (pekerja) tentang bangsa dan negaranya. Dalam diri pekerja lokal akan terinternalisasi nilai-nilai budaya China yang berlaku didalam kawasan industri tambang nikel. Selain itu, dengan beragamnya pekerja dari daerah lain yang sudah tentu membawa kebiasaan dan adatnya sendiri, telah menjadikan daerah lingkar tambang Morosi sebagai daerah dengan penduduk yang heterogen dan kompleks dalam berbagai aspek. Pada kondisi tersebut, dapat berkembang radikalisme, intoleran, faham kedaerahan dan lainnya yang akan memperlemah semangat bela negara, rasa kebangsaan dan cinta tanah air masyarakat terhadap negara Indonesia.

Sebagaimana kutipan informan Pak Bahar yang merupakan salah satu tokoh masyarakat, berikut kutipannya:

"Terdapat tulisan yang menggunakan Bahasa China dan Bahasa Indonesia di pintu gerbang masuk areal pabrik dan pemukiman masyarakat, toko penjual pakaian, penjual pulsa, warung atau rumah makan, tukang cukur dan lainnya. Ini dilakukan sendiri oleh pemiliknya. Dengan adanya tulisan-tulisan China ini secara positif memudahkan pekerja China untuk mendapatkan sesuatu yang dibutuhkan. Sebaliknya, pemilik tempat usaha mudah menjajakan barang atau jasanya. Namun, sisi negatifnya, warga dibiasakan dengan bahasa dan suasana China, yang sudah tentu akan mempengaruhi penggunaan bahasa sehari-hari warga lokal yaitu bahasa Tolaki serta bahasa Indonesia. Selain itu, para warga pendatang daridaerah lainnya kurang peduliter hadap kegiatan perayaan hari 
kebesararan atau kenegaraan, seperti Hari Kemerdekaan Indonesia, Sumpah Pemuda, Hari Pancasila dan lainnya"

Pembinaan bela negara dan wawasan kebangsaan masyarakat, merupakan salah satu tanggungjawab Badan Pembina Desa(Babinsa) sebagai aparatteritorial yang bertugas di daerah lingkar tambang Morosi. Babinsa bertugas menjamin wilayah binaannya terbebas dari berbagai pengaruh yang dapat memperlemah nasionalisme masyarakat. Sebagaimana kutipan informan Has yang merupakan salah satu Babinsa, berikut kutipannya:

"kami Babinsa yang bertugas di daerah ini, apabila ada hari besar kenegaraan, selalu mengingatkan para kepala desa dan mengajak masyarakat darirumah kerumah untuk berparti sipasi aktif pada kegiatan sosial atau olah raga supaya tertanam rasa persaudaraan dan jiwa nasionalis medalam masyarakat".

Walaupun dengan kemampuan dan kesempatan yang sangat terbatas, Babinsa berupaya berkomunikasi dan menyadarkan masyarakat binaannya agar tidak terpengaruh oleh ideologi yang melekat pada pekerjadari China. Babinsajuga melakukan pemantauan terhadap kegiatan orang asing lainnya. Apabila adakegiatan di wilayahnya yang dapat merugikan negara maupun mengancam stabilitas daerah, Babinsa dengan segera melaporkan ke Komando Rayon Militer (Koramil) Sampara, selanjutnya berjenjang ke Satuan Atas.

Armawi dan Wahidin (2019) menyebut bahwa dengan melihat perkembangan lingkungan strategis saat ini, maka 25 (duapuluh lima) tahun kedepan Indonesia tidak akan menghadapi invasi militer. Dengan demikian Binter tidak hanya ditujukan untuk membina geografi, demografi dan kondisisosial, agar memiliki kesiapan menghadapi agresi militer. Bin terlebih dititik beratkan pada upaya mengajak masyarakat dan instan siterkait sertape merintah agar dapat meningkatkan kepekaan dan kepedulian terhadap berbagai permasalahan teritorial di wilayahnya supaya tidak terjadikonflik yang berpotensi mengganggu kedaulatan dan keutuhan wilayah NKRI. Bapak Andi Mappiyang merupakan Tokoh Masyarakat DesaTani Indah menyatakan:

"Sejak di wilayah ini (Morosi) berdiri pabrik nikel, sering terjadi perkelahian di kalangan masyarakat. Dan yang lebih parah kadang menimbulkan konflik antara warga pendatang dengan penduduk lokal. Saat ini juga telah terbentuk banyak organisasi kemasyarakatan yang mengatasnamakan suku tertentu dengan kepentingan yang berbeda serta penampilan identitas kelompok yang arogan, sehingga sering terjadi gesekan dengan masyarakat setempat. Selainitu, banyak warga non-lokal yang datang tanpa keahlian, sehingga tidak dapat diterima menjadi pekerja atau karyawan di perusahaan PT. VDNI dan PT. OSS serta subkontaktornya. Sebagian dari mereka tetap tinggal di daerah ini dan menjadi 
penganggur. Sudah tentu mereka berpotensi mengganggu keamanan wilayah Morosi"

Berdasarkan pemahaman tersebut, Babinsa melaksanakan pemantauan wilayah, patroli dan pengamanan secara terpadu bersama Kepolisian dan satuan pengamanan perusahaan di sekitar lokasi pabrik nikel dan dipemukiman penduduk. Babinsa dan Bhayangkara Pembina Keamanan dan Ketertiban Masyarakat (Babinkamtibmas) melaksanakan deteksi dini dan cegah dini terhadap berbagai kemungkinan ataupotensi kerawanan, dampak dari perubahan Morosi sebagai daerah sangat terbuka. Banyaknya penduduk yang masuk dan bekerja, namun tidak terdata dalamadministrasi pemerintahan setempat, mulai dari tingkat rukun tetangga, rukun warga, Desa sampai ke Kecamatan. Bapak Muksin yang juga merupakan tokoh masyarakat Kecamatan Kapoila menjelaskan bahwa:

"Saat ini sistem pengamanan perusahaan tambang kurang baik, sehinggasering terjadi kecelakaan kerja maupun kriminalitas seperti pencurian, perkelahian dan lainnya yang dapat menimbulkan permusuhan antara perusahaan dengan pekerja maupun masyarakat, termasuk antara kelompok dalam masyarakat. Warga sangat membutuhkan peran Babinsa bersama Babinkamtibmas untuk membantu pemerintah desa dan pihak perusahaan menciptakan rasa aman dalam masyarakat yang terdiri dari berbagai macam suku. Kami mengharapkan ada Organisasi Pengamanan yang bisa mewadahi kegiatan bersama untuk mencegah ataumengatasi terjadinya konflik di masyarakat. Kami berharap para aparat teritorial tidak memihak keperusahaan apabila memediasi dan mengatasi pertikaian atau masalah keamanan di daerah ini"

Khususnya di kawasan operasional, termasuk lokasi pabrik nikel PT. VDNI dan PT. OSS maupun di jetty (dermaga kapal untuk pengangkutan ore dan veronikel), Komando Distrik Militer 1417 Kendari melaksanakan kerjasama pengamanan dengan pihak perusahaan dengan tujuan menjamin situasi keamanan masyarakat yang bebas konflik horizontal. Pelaksana dari Komando Distrik Militer 1417/Kendari ialah Komando Rayon Militer Sampara beserta jajaran Babinsa yang mempunyai wilayah binaan di Kecamatan Morosi. Sejumlah 15 (lima belas) Aparat Teritorial, termasuk Babinsa setempat, bertugas mendeteksi, menangkal, mencegah, dan menindak secara dini berbagai bentuk potensi gangguan keamanandilingkungan perusahaan sesuai dengan ketentuan perundang-undangan.

Dengan pertimbangan PT. VDNI dan PT. OSS dapat dikategorikan sebagai objek vital negara, maka pembinaan teritorial diarahkan pada kegiatan pengamanan sarana, prasarana, aset, termasuk pembinaan terhadap karyawan yang menjadi lingkup tugas dan kewenangan serta pembinaan terhadap masyarakat di wilayah sekitar perusahaan. Hasil wawancara dengan beberapa warga desa Labeso Morosi menyatakan: 
"kami warga Morosi sangat mengharapkan suasana kondusif di wilayah ini, agar perusahaan bisa berjalan normal, yang sudah tentu memberikan dampak positif bagi pekerja pabrik serta yang berprofesi pada sektor dagang, buruh dan lainnya. Kami mengharap: (1) Aparat Teritorial (Babinsa) beserta aparat Kepolisian dapat menjadi motivator keamanan masyarakat dan selalu menanggapi setiap keluhan masyarakat berkaitan dengan gangguan keamanan,

(2) Babinsa diharapkan berfungsi sebagai Body Guard masyarakat dari adanya oknum yang mengganggu ketenteraman masyarakat, (3) Aparat Teritorial dapat lebih cepat memahami masalah keamanan yang timbul di daerah dan melakukan upaya-upaya nyata, (4) agar ditingkatkan jumlah Babinsa yang bertugas di daerah Morosi, mengingat kondisi Morosi yang sangat rentan dengankonfliksosial"

Kerjasama pengamanan berpengaruh positif terhadap tingkat keamanan di wilayah lingkar tambang Morosi. Hal ini terlihat, pada saat berlaku kerjasama pengamanan tahun 2019 antara PT. VDNI dan PT. OSS dengan Kodim 1417/Kendari tidak ada gangguan keamanan yang menonjol selama tahun tersebut. Namun, ketika kerjasama pengamanan dihentikan sejak bulan Maret 2020, dimana Babinsa tidak diperkenankan masuk ke kawasan operasional perusahaan. Potensi kerawanan yang menjurus ke konflik tidak dapat dideteksi oleh Satuan Pengamanan Internal perusahaan. Akibatnya, setelah terjadi beberapa kali aksi unjuk rasa destruktif, pada tanggal 14 Desember 2020 terjadi demontras iburuh terbesar. Aksi ini kemudian melibatkan berbagai elemen masyarakat, Serikat dan Perlindungan Tenaga Kerja (SPTK) Kabupaten Konawe dan afiliasinya Dewan Pengurus Wilayah Federasi Kesatuan Serikat Pekerja Nasional (DPW F-KSPN) Provinsi Sulawesi Tenggara (CNBC Indonesia, 15 Desember 2020). Massa yang berjumlah ratusan orang membuat rusuh, merusak dan membakar smelter, puluhan kendaraan dump truk dan alat berat ekskavator dan fasilitas lainnya, dengan kerugian mencapai 200 (dua ratus) milyar rupiah.

Wilayah Morosi beberapa tahun terakhir ini, sering mengalami bencana alam banjir. Disamping, akibat adanya curah hujan yang tinggi di wilayah Sulawesi Tenggara yang pada saat bersamaan meluapnya air di hilir Sungai Konaweha, juga disebabkan perubahan dan peralihan fungsi lahan dari sawah atau tambak menjadi bangunan industri serta pemukiman baru, telah mengurangi jumlah luas resapan air. Bapak Sikadi yang merupakanTokoh Masyarakat/Purnawirawan TNI AD menyatakan bahwah:

"Para Babinsa di daerah ini, menyadari dirinya bahwa mereka anggota Tentara Nasional Indonesia yang berasal dari rakyat, sehingga pengabdian tugasnya untuk kepentingan rakyat. Apabila rakyat mengalami kesulitan, seperti ketika masyarakat mengalami dampak bencana alam. Mereka turun langsung di 
daerah bencana dan dengan alat peralatan sederhana mengorganisir dan melakukan pertolongan pertama pada masyarakat yang terkena dampak banjir"

Pada tahun 2013 dan 2019 terjadi banjir sampai ketinggian4 meter yang menggenangi ratusan hektar sawah, tambak dan pemukiman penduduk serta ruas jalan di daerah lingkar tambang Morosi, yang menyebabkan arus lalulintas terputus. Komando Rayon Militer Sampara, termasuk Babinsa dengan unsur pemerintah daerah Konawe dan Kepolisian yang tergabung dalam Badan Penanggulangan Bencana Daerah (BPBD) melakukan beberapa kegiatan, yaitu evakuasi atau penyelamatan terhadap warga yang terjebak banjir, mendirikan Posko, dapur umum maupun tenda penampungan warga yang terdampak banjir, pengobatan massal, perbaikan beberapa rumah penduduk yang rusak dan lainnya. Seperti yang disampaikan Bapak Marhadi yang merupakan Kepala Desa Purui:

"Keberadaan Komando Teritorial (Komando Distrik Militer 1417/Kendari dan Komando Rayon Militer Sampara) beserta Bintara Pembina Desa di daerah ini sangat membantu pemerintah desa. Masyarakat mau ikut berpartisipasi secara bersama-sama mengatasi masalah bencana alam, apabila diajak oleh aparat teritorial (Badan Pembina Desa)"

Pada saat daerah dalam keadaan aman bencana, aparat Komando Rayon Militer Sampara, termasuk Babinsa wilayah Morosise cara insidentil mensosialisasikan kemasyarakat tentang cara penanganan dampak bencana alam banjir yang sering dialami masyarakat di daerah tersebut. Bersama pemerintah kecamatan serta komponen masyarakat membuat peta dan kajian daerah rawan bencanabanjir.

Melalui kegiatan Bhakti TNI, Aparat TNI AD aktif menangani pandemi Covid 19. Setiap hari aparat teritorial di daerah membantu Gugus Tugas Percepatan Penanganan Covid-19 daerah. Berbagai kegiatan dilakukan, mulai dari mensosialisasikan protokol kesehatan, membantu penyaluran logistik, penyiapan sarana dan prasarana kesehatan, vaksinasi dan pengawasannya serta kegiatan lainnya. Agar tugas ini sampai keseluruh wilayah dan berbagai lapisan masyarakat, maka digunakan SatuanTeritorial sampai ketataran bawah. Sersan Sar menyampaikan bahwa:

"Padasaat Covid - 19 mewabah di seluruh Indonesia sampai kepelosok daerah termasuk di daerah Morosi, Komando Teritorial beserta Babinsa merespons dengan cepat perintah pimpinan Tentara Nasional Indonesia maupun kebijakan pemerintah daerah dalam menghadapi kondisi kritis ini agar kesehatan dan keselamatan masyarakat Morosi tetap terjamin. Babinsa ditunt utuntuk peduli, proaktif dan turut berkontribusi secara positif dalam percepatan penanganan Covid-19 di daerah"

Sepanjang bulan April sampai dengan Desember tahun 2020 Aparat Komando Rayon Militer Sampara membagikan masker kepada warga kurang lebih 5000 
lembar, mendirikan dapur umum dan penyaluran bantuan sembako daris atuan Tentara Nasional Indonesia maupun pemerintah daerah. Bersama aparat kepolisian daerah serta satuan polisi pamong paraja, tenaga kesehatan serta pemerintah kecamatan Morosimen dirikan Posko, melaksakan patroli penegakan disiplin dalam upaya percepatan penanganan Covid - 19 dan sosialisasi kepada seluruh lapisan masyarakat tentang mencuci tangan, memakai masker dan menjaga jarak. Selain itu, membuat gerbang strerilisasi untuk pengguna jalan dan kendaraan yang masuk ke wilayah Morosi serta melakukan pengecekan suhu. Membantu tenaga medismengedukasi masyarakat ditempat-tempat keramaian seperti di pasar tradisional. Salah seorang Staf Kecamatan Morosi menyampaikan bahwa:

"Banyak warga yang tidak mau mematuhi protokol kesehatan. Masih ada masyarakat yang tidak percaya dengan mewabahnya Covid-19. Mereka terpengaruh dengan opini yang menganggap pindemi Covid-19 hanyalah cerita fiktif. Pada kondisi seperti ini, aparat teritorial terkadang secara tegas melakukan tindakan pendisiplinan memakai masker dan menjaga jarak terhadap masyarakat. Adapun keikutsertaan masyarakat secara massif dalam mensukseskan upaya penanganan covid-19, dilakukan melalui proses mobilisasi"

Partisipasi teritorial adalah pelibatan atau partisipasi masyarakat pada kegiatan pembinaan teritorial yang dilaksanakan oleh Komando Teritorial di suatu wilayah, baik pada aspek geografi, demografi maupun kondisisosial dalam rangka membantu pemerintah daerah menciptakan rasa aman dan meniada kankonflik dalam masyarakat, menyiapkan kekuatan pertahanan yang meliputi wilayah pertahanan dan kekuatan pendukungnya serta terwujudnya kemanunggalan TNIRakyat.

Mengutip pandangan Cohenand Uphoff(1977), faktor yang mempengaruhi partisipasi masyarakat di lingkar tambang Morosi terhadap kegiatan Binter yang dilakukan para Bintara Pembina Desa, mencakup karakteristik individu yang dapat mempengaruhi individu tersebut untuk berpartisipasi dalam suatu kegiatan Binter, yaitu umur, jenis kelamin, status dalam keluarga, tingkat pendidikan, etnis, agama, bahasa, pekerjaan, tingkatpendapatan, jarakrumahdenganlokasi pekerjaan atau aktivitas dan kepemilikantanah.

Dari beberapa variabel karakteristik masyarakat yang diteliti, hanya variabel usia, jenis kelamin, jenis pekerjaan dan jarak rumah dengan lokasi pekerjaan serta aktivitas dan kepemilikan tanah yang memberikan pengaruh signifikan terhadap tingkat partisipasi masyarakat. Pada umumnya warga laki - laki yang sudah dewasa (20 tahun sampai dengan 50 tahun) berpartisipasi pada kegiatan Bakti TNI, membantu penanganan bencana alam dan ikut serta mengatasi konflik yang terjadi di wilayah lingkar tambang Morosi. Sedangkan dari jenis pekerjaan, petani, pengolahan pasir sungai dan warga yang tidak memiliki pekerjaan tetap, 
berpartisipasi aktif dibanding dengan profesi yang lain. Warga yang bekerja di perusahaan tambang nikel PT. VDNI dan PT.

OSS tidak aktif dalam kegiatan Binter, disebabkan waktu mereka lebih banyak beraktivitas di dalam lingkungan perusahaan dan pada saat diluar jam kerja, mereka lebih mengutamakan isterahat di rumah maupun di kamar kos.

Pembantu Letnan Dua Sar sebagai koordinator Babinsa di wilayah lingkar tambang Morosi menjelaskan bahwa:

"saat ini warga Morosi sangat sedikit yang ikut berpartisipasi pada kegiatan baktisosial maupun sosialisasi wawasan kebangsaan dan bela negara, karena pada umumnya warga bekerja diperusahaan tambang atau beraktifitas di smelter (Pabrik) nikel dari pagi sampai malam".

Sebagian besar masyarakat mengalami perpindahan profesi. Sebelumnya mereka bermata pencaharian bertani dan berkebun, yang tidak terikat dengan waktu kerja. Sekarang mereka telah bekerja sebagai karyawan perusahaan PT. VDNI dan PT. OSS serta sub kontaktornya, dengan jam kerja yang ketatdengan jam kerja 24 jam diatur kedalam 3 shift.

Semakin positif penilaian dan citra tentang TNI AD beserta KomandoTeritorial yang terbangun dalam suatu kelompok masyarakat, semakin tinggi pula keinginan masyarakat tersebut, untuk berperan membantu aparat teritorial menangani dampak bencana alam, pindemi covid 19, membangun semangat bela negara dan wawasankebangsaan Indonesia, mencegah dan menyelesaikan konflik yang terjadi antara perusahaan beserta tenaga kerja asing (China) dengan pekerja lokal maupun kelompok masyarakat lainnya.

Kepala Desa Morosi Budi Santoso menjelaskan bahwa:

"pada umumnya masyarakat tidak tertarik mengikuti kegiatan pembinaan teritorial pada tahap perencanaan maupun pengawasan, sepertirapat, pertemuan, diskusi untuk memberikan gagasan atau koreksi terhadap rencana dan hasil suatu kegiatan. Mereka lebih tergugah untuk terlibat pada tahap pelaksanaannya dengan kegiatan yang bermanfaat atau bersentuhan langsung kepada kebutuhan mereka"

Syamsuddin, salah seorang masyarakat Morosi menyampaikan bahwa:

"dengan adanya industri tambang di daerah Morosi, masyarakat lebih mengutamakan kegiatan yang dapat secara langsung memberi keuntungan untuk pemenuhan kehidupannya"

Dari hasil wawancara terhadap beberapa orang warga Desa Morosi, mereka menyampaikan bahwa: 
"masyarakat jarang berpartisipasi dalam kegiatan pembinaan teritorial, disebabkan ketidaktahuan bagaimana cara pelibatan dan peran mereka pada suatu kegiatan".

Pada umumnya masyarakat berpartisipasi dalam kegiatan yang dilaksanakan oleh aparat teritorial, apabila lokasi kegiatan berada atau dekat dengan rumah mereka (terbatas dalam hubungan Rukun Tetangga). Demikian pula, jika lahan atau hunian mereka yang menjadi sasaran kegiatan bakti sosial, maka aktivitas masyarakat sangat tinggi. Sebaliknya, sangat terbatas keterlibatan masyarakat terhadap sasaran publik maupun kegiatan sosial, apabila jauh dari pemukimanmereka. Dalam hal ini, nilai-nilai kegotongroyongan, rasa dan semangat kebersamaan semakin rendah dalam hubungan masyarakat desa.

Persepsi masyarakat terhadap Komando Teritorial juga merupakanfaktor yang signifikan mempengaruhi tingkat partisipasi teritorial. Persepsi positif terbentuk dalam masyarakat, apabila mereka mendapatkan rasa aman, damai, teratur serta keuntungan atas perlindungan terhadap personal, keluarga maupun kegiatan usaha dan harta bendanya. Sedangkan persepsi negatif oleh adanya perlakuan menyimpang dari aparat teritorial, termasuk perlakuan diskriminasi, intimidasi atau tindakan represif yang dilakukan oknum aparat TNI (teritorial) terhadap perorangan atau suatu kelompok masyarakat.

Hal lain yang menyebabkan rendahnya partisipasi teritorial masyarakat terhadap kegiatan pembinaan teritorial, dikarenakan kurangnya interaksi antara Babinsa dengan unsur Pemerintah desa dan masyarakat, sehingga komunikasi tidak berlangsung intensif. Dalam hal ini, 5 (lima) orang Babinsa membina 10 (sepuluh desa) dengan penduduk 10.645 jiwa, luas wilayah binaan $76,49 \mathrm{Km}^{2}$. Selain itu, Babinsa juga mengalami kendala dalam berinteraksi dengan masyarakat, karena menghadapi kondisi sosial yang kompleks dan rumit, sebagai dampak dari banyaknya orang asing dan pendatang lainnya yang tidak terdaftar dan menghuni pemukiman yang tidak tertata dengan baik. Seiring dengan terjadinya perubahan sosial, kuantitas dan kualitas gangguan keamanan semakin tinggi, yang sudah tentu menguraspikiran dan tenaga Babinsa. Dihadapkan dengan permasalahan tersebut, maka para Babinsa dalam melaksanakan tugasnya memprioritaskan pada masalah menonjol yang terjadi di wilayah binaannya.

Dengan demikian, Partisipasi Teritorial juga berlangsung secara parsial, menyesuaikan dengan sasaran kegiatan pembinaan teritorial dari Babinsa. Keberadaan Komando Teritorial menginternalisasi tradisi militer kedalam kehidupan masyarakat, sehingga lahir partisipasi teritorial yang menciptakan stabilitaskeamanan, membangun kesadaran hidup bermasyarakat secara damai, toleransi, berwawasan kebangsaan Indonesia, semangat bela negara serta berperan sebagai penengah apabila terjadi perbedaan kepentingan di tengah-tengah masyarakat yang sulit disatukan dan rawan terhadap gesekan sosial. 
Program pembinaan teritorial tidakakan berjalan tanpa adanya partisipasi masyarakat. Dalam proses pelaksanaannya, ada bermacam bentuk nyata dari partisipasi teritorial (1). Partisipasi harta benda, yaitu bentuk partisipasi dengan menyumbangkan materi berupa penyediaan dana, barang serta penyediaan sarana atau fasilitas. (2). Partisipasi tenaga, merupakan partisipasi yang diberikan dalam bentuk tenaga seseorang untuk membantu dalam menyelesaikan suatu kegiatan. (3). Partisipasi buah pikiran, yaitu dengan membantu menyumbangan ide pikiran, pengalaman dan pengetahuan dalam penyusunan suatu rancangan program atau kegiatan. (4). Partisipasi keterampilan, merupakan partisipasi dengan memberikan bantuan berupa keterampilan yang dimilikinya.

Adapun partisipasi teritorial merujuk pada empat tahapan Cohen dan Uphoff (1977) yaitu: (1) Tahap pengambilan keputusan atau tahap perencanaan. Partisipasi teritorial ini terutama berkaitan dengan penentuan alternatif dengan masyarakat berkaitan dengan gagasan atau ide yang menyangkut kepentingan bersama. Misalnya dalam program bakti sosial perbaikan rumah kumuh, masyarakat diminta menentukan prioritas beberapa rumah dan lingkungannya yang akan segera diperbaiki (renovasi). Begitu pula, pada saat Babinsa akan menentukan teknik atau sistem pengamanan yang tepat diterapkan dilingkungan perusahaan tambang, para tokoh masyarakat diajak untuk memberikan masukan (2) Tahap pelaksanaan yang merupakan tahap terpenting dalam kegiatan pembinaan teritorial. Wujud nyata partisipasi teritorial pada tahap ini digolongkan menjadi tiga, yaitu partisipasi dalam bentuk sumbangan pemikiran, bentu ksumbangan materi, dan bentuk aktifitas masyarakat yang bersama prajurit TNI turun kelapangan mengerjakan suatu kegiatan fisik. (3) Tahap menikmati hasil atau manfaat, tidak lepas dari hasil perencanaan dan pelaksanaan yang telah dicapai, baik yang berkaitan dengan kualitas maupun kuantitas. Dari segi kualitas dapat dilihat dari output, sedangkan dari segi kuantitas dapat dilihat dari presentase keberhasilan program. Dengan melihat posisi masyarakat sebagai subyek pembangunan, maka semakin besar manfaat dari objek pekerjaan dirasakan, berarti objek pekerjaan tersebut berhasil mengenai sasaran. (4) Tahap evaluasi, dianggap penting sebab partisipasi teritorial pada tahap ini merupakan umpan balik yang dapat memberi masukan demi perbaikan pelaksanaan kegiatan pembinaan teritorial selanjutnya di wilayah lingkar tambang Morosi.

\section{KESIMPULAN}

Berdasarkan hasil analisis dan pembahasan yang telah dikemukakan pada bab sebelumnya, maka dapat disimpulkan beberapa hal. Partisipasi teritorial masyarakat dalam suatu program pembinaan teritorial dipengaruhi oleh faktor usia, jenis kelamin, jenis pekerjaan dan jarak rumah denganlokasi pekerjaan serta aktivitas dan kepemilikan tanah. Selain itu, kemampuan komunikasi dan interaksi sosial Bintara Pembina Desa dalam menyelami, menghubungi, mempengaruhi dan mengajak masyarakat, memberikan pengaruh signifikan terhadap tingkat partisipasi teritorial. 
Variabel sebagai faktor yang juga berpengaruh terhadap tingkat partisipasi teritorial ialah Persepsi masyarakat terhadap Komando Teritorial. Persepsi ini menyangkut penilaian atau citra positif yang mampu menggugah masyarakat untuk berpartisipasi dalam kegiatan pembinaan teritorial di daerah lingkar tambang Morosi. Selainitu, sebagian besar masyarakat Morosi saat ini mengalami perpindahan profesi menjadi karyawan/buruh perusahaan tambang nikel dengan waktu kerja pagi sampai malam hari, sehingga mereka menghadapi keterbatasan waktu untuk berpartisipasi pada kegiatan pembinaan teritorial TNI AD. Dampak dari pengaruh faktor internal maupun eksternal, maka partisipasi teritorial rendah dalam kegiatan pembinaan teritorial yang dilaksanakan aparat teritorial/Bintara Pembina Desa di daerah lingkar tambang Morosi.

Tingkat partisipasi teritorial rendah, maka akan memperlemah kemanunggalan TNI-Rakyat dan memperkecil sumber kekuatan pertahanan semesta. Pada gilirannya masyarakat Morosi terbatas dalam mendukung aparat teritorial menyiapkan wilayah pertahanan serta perlawanan rakyat, guna menjamin terselenggaranya Sistem Pertahanan Semesta yang memiliki kemampuan menghadapi situasi kritis dan meniadakan ancaman dari dalam serta menangkal ancaman dari luar.

Daerah lingkar tambang Morosi sangat rawan terhadap konflik etnik antara pekerja asing (China) dengan masyarakat lokal serta perubahan sosial yang dinamis, membutuhkan suatu bentuk pembinaan teritorial secara khusus dari Kodim 1417/Kendari serta Koramil Sampara. Bentuk kegiatan Binter yang bersentuhan langsung dengan kebutuhan masyarakat akan mendorong atau menumbuhkan minat dan sikap masyarakat untuk berpartisipasi.

\section{UCAPAN TERIMA KASIH}

1. Kepada allah SWT yang telah memberikan kesempatan dan ijinnya sehingga rampungnya artikel ini.

2. Prof. Andi Agustang selaku Kaprodi S3 SosiologiUNM Makassar.

3. Seluruh Pengajar di S3 Prodi Sosiologi UNM Makassar.

4. Rekan Seangkatan di S3 Prodi Sosiologi angkatan 2020 UNM Makassar.

\section{DAFTAR PUSTAKA}

Agustang, A. (2011). Pendekatan Penelitian Kualitatif dan Kuantitatif Suatu Tinjauan Kritis. In Makassar: Andira Publisher. Andira Publisher.

Agustang, A. (2021). Filosofi Research Dalam Upaya Pengembangan Ilmu. OSF Preprints.

Andi Agustang. (2015). Dasar-Dasar Filsafat Penelitian Untuk Pengembangan Ilmu (I. I. Idrus (ed.); pertama). CV Multi Global.

Armawi, A., \& Wahidin, D. (2019). Eksistensi TNI dalam Menghadapi Ancaman Militer dan Nir Militer Multidimensional di Era Milenial. WIRA Edisi Khusus HUT TNI Ke 74 Tahun 2019, 1-60. Retrieved from https://www.kemhan.go.id/wp- 
content/uploads/2019/12/wiraedsus2019-web.pdf

Cohen, J. M., \& Uphoff, N. T. (1977). Rural Development Participation: Concepts and Measures for Project Design, Implementation and Evaluation. New York: Rural Development Committee, Center for International Studies, Cornell University.

Departemen Pertahanan Indonesia. (2008). Buku Putih Pertahanan Indonesia, 2008: Disahkan dengan Peraturan Menteri Pertahanan, Republik Indonesia nomor PER/03/M/II/2008 tanggal 18 Februari 2008. Jakarta: Departemen Pertahanan, Republik Indonesia.

Dilthey, W., \& Jameson, F. (1972). The Rise of Hermeneutics. New Literary History, 3(2), 229-244.

Hakim, C. (2021). Membahas Sistem Pertahanan Keamanan Rakyat Semesta. Perpustakaan Nasional Republik Indonesia. Retrieved from https://www.perpusnas.go.id/artikel-dan-opini-detail.php

Hermawan, N. (2015). Dengan Binter, TNI - Rakyat Manunggal Mengawal Kedaulatan Negeri. Https://Tniad.Mil.Id. Retrieved from https://tniad.mil.id/dengan-bintertni-rakyat-manunggal-mengawal-kedaulatan-negeri/

Kant, I. (1781). Critique of Pure Reason/Immanuel Kant (Cambridge; P. Guyer \& A. W. Wood, Eds.). New York: Cambridge University Press.

Mabesad (2018) Doktrin Induk Teritorial TNI AD.

Manik, J. D. N. (2018). Pengaturan Hukum Perbatasan Negara Kesatuan Republik Indonesia Berdasarkan Undang-Undang Wilayah Negara. PROGRESIF: Jurnal Hukum, 12(1), 2015-2027.

Moleong, L. J. (2007). Metodologi Penelitian Kualitatif (edisi revi). Bandung: PT Remaja Rosdakarya.

Octavian, A. (2012). Militer dan Globalisasi: Studi Sosiologi Militer dalam Konteks Globalisasi dan Kontribusinya bagi Transformasi TNI. Jakarta: UI Press.

Ouellet, E. (2005). New Directions in Military Sociology. Whitby: ON De Sitter Publications.

Rahadi, F. (2020). VDNI dan OSS Rekrut 3.300 Tenaga Kerja Lokal. Retrieved January9,2021,fromhttps://republika.co.id website: https://republika.co.id/berita/daerah/sulawesi/ql226h291/vdni-dan-ossrekrut-3300-tenaga-kerja-lokal

Slamet, M. (2003). Membentuk Pola Perilaku Manusia Pembangunan: Didedikasikan Kepada Prof. Dr. HR Margono Slamet (A. Sudradjat \& I. Yustina, Eds.). Bogor: IPB Press.

Slamet, Y. (1994). Pembangunan Masyarakat Berwawasan Partisipasi. Surakarta (ID): UNS Press.

Sudaryono. (2017). Metodologi Penelitian: Penelitian Kualitatif. Depok, Jakarta: PT. Raja Grafindo Persada.

Weber, M. (1946). Essay in Sociology (Noorkholis \& Promothea, Eds.). Yogyakarta: Pustaka Pelajar. 